\title{
RAC-Alpha Serine/Threonine Kinase
}

National Cancer Institute

\section{Source}

National Cancer Institute. RAC-Alpha Serine/Threonine Kinase. NCI Thesaurus. Code C17579.

RAC-alpha serine/threonine-protein kinase ( $480 \mathrm{aa}, \sim 56 \mathrm{kDa}$ ) is encoded by the human AKT 1 gene. This protein is involved in signal transduction, serine/threonine phosphorylation, apoptosis regulation and neurogenesis. 